\title{
Chinese Import Competition, Offshoring and Servitization
}

\author{
Gu, Grace; Malik, Samreen; Pozzoli, Dario ; Rocha, Vera
}

Document Version

Final published version

Publication date:

2021

License

Unspecified

Citation for published version (APA):

Gu, G., Malik, S., Pozzoli, D., \& Rocha, V. (2021). Chinese Import Competition, Offshoring and Servitization. Copenhagen Business School [wp]. Working Paper / Department of Economics. Copenhagen Business School No. $05-2021$

Link to publication in CBS Research Portal

\section{General rights}

Copyright and moral rights for the publications made accessible in the public portal are retained by the authors and/or other copyright owners and it is a condition of accessing publications that users recognise and abide by the legal requirements associated with these rights.

\section{Take down policy}

If you believe that this document breaches copyright please contact us (research.lib@cbs.dk) providing details, and we will remove access to the work immediately and investigate your claim. 
Copenhagen

Business School

HANDELSH ØJSKOLEN

\title{
Department of Economics
}

Copenhagen Business School

Working paper 05-2021

Chinese Import Competition, Offshoring and Servitization

\author{
Grace $\mathrm{Gu}$
}

Samreen Malik

Dario Pozzoli

Vera Rocha

Department of Economics - Porcelænshaven 16A, 1. DK-2000 Frederiksberg 


\title{
Chinese Import Competition, Offshoring and
}

\section{Servitization*}

\author{
Grace Gu† Samreen Malik; Dario Pozzoli ${ }^{\S} \&$ Vera Rocha
}

December 30, 2020

\begin{abstract}
This paper examines whether Chinese import competition increases the propensity for firms to offshore production or to cease any involvement in production by switching completely and permanently out of the manufacturing sector (servitization). Using a Danish employer-employee matched dataset covering a large sample of manufacturing firms over the 1995-2012 period, we find that import competition from China significantly increases offshoring but does not induce servitization. These findings are confirmed using various robustness tests as well as an analogous analysis of a Portuguese employer-employee matched dataset.
\end{abstract}

Key words: Foreign Competition, Offshoring, Servitization.

JEL code: F12, F14, O31.

\footnotetext{
*We are extremely thankful to Stephen Miller and to the seminar participants at University California Santa Cruz, Copenhagen Business School and the WEAI 2020 conference for the helpful comments and suggestions. We thank the data manager at Copenhagen Business School for granting access to the Danish registry data. The registry data build on anonymized micro datasets owned by Statistics Denmark. In the interest of the scientific validation of analyses published using Denmark Statistics microdata, the Department of Economics, Copenhagen Business School, will assist researchers in obtaining access to the dataset. Funding provided by the Danish Council for Independent Research in Social Sciences, Grant no. DFF-8019-00019B, is gratefully acknowledged. The usual disclaimer applies.

${ }^{\dagger}$ Email: grace.gu@ucsc.edu. University of California Santa Cruz.

${ }^{\ddagger}$ Email: samreen.malik@nyu.edu. New York University AD.

${ }^{\S}$ Email: dp.eco@cbs.dk. Copenhagen Business School.

ๆEmail: vr.ino@cbs.dk. Copenhagen Business School.
} 


\section{Introduction}

The surge of Chinese exports, encouraged by the country's transition to a market-oriented economy and rapid integration into world trade, has been identified as a potential factor that could alter the course of the manufacturing sector, especially within the EU. In response to the import competition from China, manufacturing firms can cut their labor costs by offshoring some or most of production activities to low-wage countries or even stop any involvement in production (including production offshoring) and switch to service activities

only (servitization, henceforth), such as becoming wholesale, consulting, or R\&D firms. A recent study on Denmark provides supportive evidence for the former argument, i.e., that foreign import competition is indeed positively associated with Danish firms' likelihood to offshore to the new EU member countries (Bernard et al., 2020). However, we know relatively little about whether and how Chinese import competition is responsible for manufacturing firms' servitization.

Does Chinese import competition induce firms to offshore production or to servitize, i.e., to stop any involvement in production and to act as pure service companies? We answer this research question by using a matched employer-employee database for Denmark covering manufacturing firms from 1995 to 2012. These data are well suited for our analysis for two reasons. First, they include detailed trade information, which allows us to measure offshoring at the firm level. This represents a significant improvement over industry-level measures of offshoring that are common in the literature, since offshoring tends to be highly firm-specific (Hummels et al., 2014a). Second, the data measure the 4-digit industry affiliation of each establishment belonging to the same firm, which allows us to identify the transition out of manufacturing by exploiting detailed information on the main activity at the plant level, as in (Bernard et al., 2017).

After studying the Danish case, we extend our analysis to Portugal to explore whether the patterns we observe in Denmark can be generalized to another small open economy. Portugal, like Denmark, is highly exposed to Chinese import competition (OECD, 2013a,b) but differs from the Danish context in many respects. For example, Portugal is characterized by a less flexible labor market and a more regulated product market than Denmark. 
Servitization has been documented in many OECD countries; see (Lodefalk, 2017) for a comprehensive literature review. However, the servitization and offshoring implications of import competition have not been studied widely; only a few papers (partially) examine this topic. Breinlich et al. (2018) shows, for example, that UK manufacturing firms react to trade liberalization by shifting toward service provision relative to goods production over the 1997-2007 period. Bernard et al. (2019) finds that trade induces Danish firms to offshore production and change their employment composition towards a much higher share of technology and research-related workers.

This paper contributes to the literature by jointly studying firms' choices of either offshoring or servitization in response to increase in Chinese import competition, as according to our definitions, offshoring and servitization are conceived as alternative strategies in firms' restructuring choice set. Moreover, we document that offshoring firms have a higher share of high-skill workers than servitization firms, consistent with the findings of Bernard et al. (2017, 2020). ${ }^{1}$ This supports the notion that offshoring and servitization involve different adjustments of firms' labor force and can be viewed as alternative modes to cope with globalization and increased competition from abroad. Hence, using Danish as well as Portuguese data, this paper studies the impact of Chinese import competition on firms' propensities to either offshore or servitize.

Given offshoring and servitization firms' different compositions of worker skills, this paper also provides another angle to explain why trade has unequal effects on different groups of workers in addition to the mechanisms highlighted in the trade literature. ${ }^{2}$

The relationship between import competition, offshoring, and servitization not only is of interest to economists but also carries important policy implications. The recent decline of manufacturing and manufacturing employment in high-income countries is documented in many papers e.g., Bernard et al., 2017), which has coincided with the rise of China in

\footnotetext{
${ }^{1}$ Bernard et al. (2017) categorize firms that switch out of manufacturing into two groups: one group completely stops any involvement in production (domestic or abroad) and conducts services only, i.e., sertivization firms as defined in our paper, while the other group outsources (offshores) production. Bernard et al. (2017) finds that the first group tends to employ a workforce with lower skills than the second group. Bernard et al. (2020) shows that firms that engage in offshoring reallocate labor away from production towards skill-intensive and technology-related occupations. These offshoring firms also experience an increase in innovation.

${ }^{2}$ Autor et al. (2015), Ferriere et al. (2018) and Gu et al. (2020), to cite a few.
} 
globalization, has been a major concern for the public and policy-makers. What is not well understood is how economic policies should deal with the decline in manufacturing employment in response to import competition from low-wage countries. On the one hand, if the main effect of Chinese import competition is to induce manufacturing firms to offshore production and specialize in knowledge-intensive activities that require mainly high-skill workers, then public policies should aim at retraining low-skill workers who are displaced by offshoring firms. On the other hand, if Chinese competition triggers servitization, in which, for example, manufacturers become wholesalers that mainly employ low-skill workers, then the policy design should focus on supporting the medium- and high-skill workers who lose their jobs as a result.

In the next section, we present data and summary statistics. Our empirical strategy is explained in Section 3. We present our results in Section 4 and conclude in Section 5. Figures and tables are given at the end of the paper.

\section{Data}

We collect firm- and worker-level information from three databases registers from the Danish official statistical institute (Denmark Statistics: the "Integrated Database for Labor Market Research" (IDA), the "Accounting Statistics Registers" (FirmStat) and the "Foreign Trade Statistics Register" (Udenrigshandelsstatistikken). From the population of all firms, we retain only private firms that are included in the first two databases over the period from 1995 to 2012 and that mainly operate within the manufacturing industry. ${ }^{3}$ Moreover, we drop firms with fewer than 2 employees. ${ }^{4}$ Next, we provide further details on how we process the data in each database.

The IDA is a longitudinal employer-employee register, containing information on, for example, the place of work, education and labor market status of each individual aged 1574 between 1980 and 2012. The information is updated once a year in week 48. Apart from deaths and permanent migration, there is no attrition in the data. From this register,

\footnotetext{
${ }^{3}$ As we clarify below, our final sample also includes manufacturing firms that switched to the service industry at some point over the sample period.

${ }^{4}$ The size criteria reduce the inclusion of self-employed individuals.
} 
we keep only individuals who are employed full time every year from 1995 to 2012. The individual information in the IDA is used to measure a number of workforce characteristics at the firm level, such as employees' education.

Our second database is the Firm Statistics Register (FirmStat henceforth), which covers the universe of private-sector firms over the years 1995-2012. It provides the annual value of firm productivity ${ }^{5}$ and the 4-digit level classification of the Danish Industrial Activities. ${ }^{6}$

The third dataset is drawn from the Foreign Trade Statistics Register and is available from 1993 to 2012. ${ }^{7}$ It contains information on import (and export) sales and the number of imported (and exported) products at the firm level for the same period as FirmStat. The trade data measured at the firm level are used to construct our offshoring measure. From these data, we also construct our measure of import competition at the industry level. This measure is based on import sales by product at the 4-digit level classification of the Danish Industrial Activities. More specifically, we map international import data at the 6-digit product level to the 4-digit industry level by merging the Foreign Trade Statistics Register with FirmStat, where we observe the industry code for each firm. To construct our instruments, as explained in the next section, we aggregate these flows at the 4-digit level and merge them with the U.N. COMTRADE data. ${ }^{8}$

\subsection{Descriptive Statistics}

The first panel in Table 1 reports the descriptive statistics of the main dependent variables used in the empirical analysis. We first estimate the impact of import competition on the firm-level intensive and extensive margins of offshoring. We then examine the probability of servitization.

\footnotetext{
${ }^{5}$ Firm productivity is calculated as turnover per employee on a logarithmic scale (i.e., labor productivity). We deflate all monetary values using the World Bank's GDP deflator with 2005 as the base year.

${ }^{6}$ For multi-establishment companies, we are able to identify the 4-digit industry of affiliation of each establishment belonging to the same firm. This information allows us to measure the transition out of manufacturing by exploiting detailed information on the main activity at the plant level, as explained in the next section.

${ }^{7}$ We use 1993 as a pre-sample year in the construction of our instrumental variables, as explained in the next section. The sample period used in all regressions runs from 1995 to 2012.

${ }^{8}$ The first 6 digits of the Combined Nomenclature in the Foreign Trade Statistics Register are the same as the product classification in the COMTRADE data, i.e., the HS classification. However, we use 4-digit level aggregation to considerably improve consistency over time.
} 
Using data from the Foreign Trade Statistics Register, we calculate a firm-level measure of offshoring. As in Feenstra and Hanson (1999) and Hummels et al. (2014b), we construct a "narrow offshoring" measure that is defined as the summation of a firm's imports in the same HS4 category as its exports. ${ }^{9}$ The first row of Table 1 shows that approximately 20 percent of manufacturing firms engage in offshoring, according to our narrow measure. When we examine the intensive margin of offshoring in the second row, we find that the average value of offshoring is approximately 9 million Danish Krone.

The third row of Table 1 reports the average servitization rate, which is 4 percent. Similar to Bernard et al. (2017), we classify a servitization firm at time $t$ if the following conditions are fulfilled. First, the firm does not offshore production from time $t$ onward according to the narrow measure described above. Second, at time $t-1$, at least one of its establishments was classified as a manufacturing establishment, and at least 10 percent of its workforce was employed in this establishment. Third, none of its establishments is classified in manufacturing from time $t$ onward. Our definition of servitization implies that we are able to reliably identify permanent switchers from 1996 through 2012.

[Insert Table 1 about here]

The remainder of Table 1 shows the descriptive statistics of the independent variables used in our regression models at the firm level, including firm productivity and size, among others.

As we explain more extensively in the next section, the central explanatory variable of the empirical analysis is import competition from China, which is measured as the log of the weighted sum of Chinese imports of all HS products by the EU-15 and the US. Descriptive statistics are presented in the second panel of Table 1. Similar to Hummels et al. (2014a), the instrument of our import competition variable, reported in the second row, is calculated from COMTRADE and is based on the shocks to the Chinese export demand originating from 4 high-income countries, i.e., Australia, Canada, Japan, and New Zealand. In addition, we calculate an alternative import competition measure by using import values not from China but from new EU members, i.e., Czech Republic, Estonia, Hungary, Latvia, Lithuania,

\footnotetext{
${ }^{9}$ Given the richness of the data, for multi-product firms, we are able to sum imports across all of the HS4 products that the firm also exports.
} 
Poland, the Slovak Republic, Slovenia, Cyprus, and Malta, which joined the EU in 2004, and Bulgaria and Romania, which joined in 2007 (Dauth et al., 2014). The corresponding instrument is calculated as the total export values from these new EU member countries to the 4 high-income countries.

Figure 1 shows the basic time-series variation in the share of firms that offshore production abroad (top left panel), the share of firms that servitize (top right panel) and the import competition variable (bottom panel) over the sample period for the manufacturing industry in Denmark. There is a clear positive trend in all variables. The offshoring (servitization) rate increased from approximately 14 (2) percent in late 1990s to approximately 20 (8) percent in 2012. Over the same sample period, our import competition variable at the industry level increases on average from approximately 19 to approximately 22, an increase of 300 percent.

\section{[Insert Figure 1 about here]}

Figure 2 presents the five manufacturing industries with the highest share of offshoring firms in Denmark. Offshoring is most common for the manufacturing of fabricated metals and textiles, where more than 60 percent of firms offshore, followed by computers and chemicals (more than 40 percent of firms offshore) and other transport equipment (just below 40 percent of firms offshore). Figure 3 presents evidence on the share of firms that switch completely and permanently out of manufacturing by the top five industries of origin and the top five industries of destination. We find that the food industry features the highest servitization rate (60 percent of all switchers are concentrated in this industry), followed by machinery and equipment (11 percent). The most popular destination industry for switchers is the wholesale and retail trade industries (more than 30 percent of all switchers end in one of these two service industries). Approximately 30 percent of all switchers move to other service industries that are traditionally low-skill intensive, such as restaurants, construction, and transportation. This finding is in line with the notion that the firms that choose to stop production completely and switch permanently out of manufacturing are often wholesalers or service companies that focus mainly on tasks that are low-skill intensive.

Furthermore, Figure 4 confirms that the share of high-skill workers is higher and has been increasing at a faster rate in offshoring firms than in servitization firms over the sample pe- 
riod. The opposite holds true for the share of low-skill workers, i.e., on average, servitization firms feature a higher share of low-skill workers compared to offshoring firms, especially in the years towards the end of the sample period. As a result, the gap in the share of low-skill workers between these two types of firms has clearly increased. Additional descriptive statistics across firm types reveal that on average, servitization firms are smaller, less productive and have a lower share of high-skill workers than offshoring firms (see Table A-0 of the online appendix).

[Insert Figures 2, 3 and 4 about here]

\section{Empirical strategy}

Our estimation strategy first examines the impact of Chinese import competition on firms' offshoring and servitization decisions. For all these outcomes, we estimate the following linear probability model:

$$
\text { Outcome }_{i j t}=\alpha_{0}+\beta_{1} \operatorname{Imp}_{j t-1}^{C H}+X_{i j t-1}^{\prime} \gamma_{1}+\delta_{i}+\delta_{m}+\delta_{t}+\epsilon_{i j t}
$$

where the dependent variable, Outcome $i j t$, is the offshoring or servitization decision of firm $i$ in 4-digit industry $j$ in year $t$.

Our main independent variable, $\operatorname{Im} p_{j t-1}^{C H}$, measures the level of Chinese import competition and is calculated as follows:

$$
\operatorname{Imp} p_{j t-1}^{C H}=\log \left(\sum_{p=1}^{P} \frac{\text { exports }_{j p 1995}}{\text { exports }_{j 1995}} \operatorname{Imp}_{p t-1}^{C H-E U 15-U S}\right)
$$

where $I m p_{p t-1}^{C H-E U 15-U S}$ is the total purchases of product $p$ from China at time $t-1$ by the EU-15 countries (including Denmark) and the US. ${ }^{10}$ We include the imports from the other EU-15 countries (beside Denmark) and the US to capture that the rise in Chinese exports affects Danish firms not only through intensifying competition in the domestic market but also in foreign markets to which Danish firms export and therefore compete with Chinese

\footnotetext{
${ }^{10} \mathrm{As}$ an alternative definition, we calculate our import competition variable using import values from new EU members (Dauth et al., 2014).
} 
products. ${ }^{11}$ The weights, $\frac{\text { exports } s_{j p 1995}}{\text { exports } s_{j 1995}}$, are export shares, which are time invariant (i.e., 1995) and industry specific. ${ }^{12}$ The variable export ${ }_{j p 1995}$ represents Danish industry $j$ 's export value of product $p$ to the world market in year 1995, whereas export ${ }_{j 1995}$ denotes Danish industry $j$ 's total exports to the world market in the same year. Import competition and the other independent variables are lagged to account for companies' inability to immediately respond to changing economic conditions, among other factors. ${ }^{13}$

The vector $X_{i j m t-1}$ includes a sector-by-year Herfindahl index (to control for the degree of domestic competition) and a set of firm characteristics that could influence our firm-level outcomes, such as firms' productivity, adoption of robots, size and share of high-skill workers. The inclusion of productivity in our specification controls for the potential "productivity effect" associated with obtaining access to cheaper or better foreign inputs, which may influence offshoring and servitization decisions. A recent study on Denmark (Humlum, 2019) shows that the adoption of industrial robots induces manufacturing firms to reorganize production around knowledge-intensive and R\&D tasks. To control for this channel, which may confound the impact of import competition, especially on offshoring, we include a dummy variable equal to 1 if the firm imports robots. ${ }^{14}$ All these additional control variables at the firm level allow us to focus more carefully on the effects of import competition. Furthermore, we incorporate firm fixed effects $\left(\gamma_{i}\right)$, two-digit sector $\left(\gamma_{t}\right)$ and year fixed effects $\left(\gamma_{t}\right)$

One possible threat to the identification and estimation of the coefficient of $\beta_{1}$ is that Chinese import competition is likely to be endogenous in regression (1), as unobserved productivity shocks may be associated with both firms' outcomes and imports. To obtain an unbiased estimate of this parameter, we instrument $I m p_{j t-1}^{C H}$ with exogenous shocks to the Chinese export demand in a 2SLS estimation. Similar to Hummels et al. (2014a), the instrumental variable $I m p_{j t-1}^{I V}$ is calculated as follows:

\footnotetext{
${ }^{11}$ Danish export sales to the other EU-15 countries and the US represent more than 70 percent of total exports over the sample period (OECD, 2015).

${ }^{12}$ We use time-invariant (base-year) industry-specific export shares as weights to reduce endogeneity issues.

${ }^{13}$ Very similar results are obtained by using longer lags (see Table A-1 in the online appendix). We also try a nonlinear specification, and the coefficients estimated on both the import competition variable and its squares are not statistically significant for both the outcomes of offshoring and servitization (also reported in Table A-1).

${ }^{14}$ Similar to Humlum (2019), we construct robot adoption on the basis of information on imported robots.
} 


$$
I m p_{j t-1}^{I V}=\log \left(\sum_{p=1}^{P} \frac{e x p_{j p_{\_} 1993}}{e x p_{j \_1993}} \operatorname{Im} p_{p t}^{C H-H I}\right)
$$

where $I m p_{p t}^{C H-h i}$ is 4 high-income countries' total purchases of product $p$ from China at time t, weighted by the base-year (1993) Danish export shares, which are constant, industryspecific and calculated two years before our sample period starts. Similar to Autor et al. (2013), we consider the following high-income countries: Australia, Canada, Japan, and New Zealand.

While our instrument is centered on the base year of Danish export shares and therefore not subject to the same contemporaneous forces that affect the firms' outcomes, we require our instrument to be independent from any expectations in future trends of the same outcomes. We test such restriction by regressing the change in our instrument from 1995 to 1998 on the change in the firms' outcomes (offshoring and servitization) at the 4-digit industry level in the pre-sample period, i.e., 1993-1995. Column 1 of Table 3 shows that we cannot reject the hypothesis of no correlation between our instrument and pre-trend growth of the main outcome variables used in the empirical analysis at the firm level. This result is robust to alternative periods used to calculate the growth rate of our instrumental variable (see columns 2-4 of Table 2).

[Insert Table 2 about here]

\section{Results}

In this section, we present the effects of import competition. First, we examine whether the increase in Chinese competition affects Danish firms' offshoring decisions. Second, we focus on whether competition influences firms' probability of switching completely and permanently out of manufacturing, i.e., servitization. Finally, we extend the analysis to Portugal to assess whether similar effects occur in another context that is characterized by different institutional and labor settings. 


\subsection{Import Competition and Offshoring}

We estimate the impact of Chinese import competition on the extensive margin of offshoring with the linear probability equation (1), after controlling for firm characteristics and firm, sector and year fixed effects. In this relatively straightforward specification reported in column 2 of Table 3, we see that Chinese import competition is positively related to the probability that a manufacturing firm will offshore production abroad. The import competition coefficient of 0.00141 implies that a 100 percent increase in import competition at time $t-1$ is associated with a less than 1 percent increase in the extensive margin of offshoring at time $t$. Column 1 reports the estimated marginal effect from a probit specification. Reassuringly, we see that the import competition coefficient in the linear probability model (column 2) and the probit model (column 1) are both positive and statistically significant. ${ }^{15}$

Having established that our results are robust to an alternative specification based on the probit model, we now proceed with additional estimations using our preferred linear probability specification. In column 3, we turn to our instrumental variable approach to address endogeneity concerns. The first-stage result shows that the instrument has a significant positive impact on import competition (see bottom panel of Table 3). The first-stage F-stat is well above 17 , indicating a strong first stage. ${ }^{16}$ The second-stage result shows that exogenous Chinese import competition significantly increases the likelihood of offshoring, and it now carries a causal interpretation. Specifically, a 100 percent increase in import competition leads to a 0.00634-percentage-point increase in the probability that a firm within that manufacturing industry will offshore, which corresponds to a 3 percent increase.

Moreover, the import competition coefficient in the IV specification (column 3) is larger in magnitude than the analogous OLS coefficient (column 2). This result is consistent with the

\footnotetext{
${ }^{15}$ Following the existing literature (Damm and Dustmann, 2014; Miguel et al., 2004), we prefer the flexibility of the linear probability model, especially since our analysis is based on employing an instrument variable for import competition, which is more challenging in a probit specification. The linear probability model is unbiased and consistent as long as few of the predicted probabilities lie outside the unit interval (Horrace and Oaxaca, 2006). Moreover, Angrist and Pischke (2010) deem the linear probability model a preferable approach, especially when the nature of the nonlinear model is unknown.

${ }^{16}$ Note that the rule of thumb of 10 is meant only for special cases, such as the case of no cross-sectional or time-series correlation in the error term. For more complex autocovariance structures, Olea and Pflueger (2013) suggest an F-stat threshold of 17 instead. Even considering this higher rule of thumb, we do not face a weak instrument problem in any of our specifications.
} 
following endogeneity concern. An unobserved positive productivity shock at the industry level may induce more firms in that industry to offshore and simultaneously to be less exposed to import competition from abroad. As a result, there is a spurious negative bias in the OLS coefficient reported in column 2. Our instrumental variable approach addresses this issue, and thus, in column 3, the causal impact of Chinese import competition on offshoring is of a larger magnitude.

In column 4 of Table 3, we redefine the import competition variable by focusing on Danish imports from new EU member countries. ${ }^{17}$ EU-15 countries, including Denmark, experienced an unprecedented increase in trade with these new EU members over the course of the sample period (Dauth et al., 2014). The results show that import competition calculated in this alternative definition still has a significant positive impact on the extensive margin of offshoring, which is similar in magnitude to our baseline specification.

Then, we examine the impact of import competition by including only high-productivity and tech firms (column 5) and by excluding those firms from the sample (column 6). ${ }^{18} \mathrm{We}$ find that only high-productivity and tech firms significantly respond to import competition in terms of the likelihood of offshoring, as the coefficient estimated for the other group of firms is not precisely estimated.

Finally, we estimate the impact of Chinese import competition on the intensive margin of offshoring. Column 7 of Table 3 uses the logarithm of offshoring volumes as the dependent variable, conditional on the firm offshoring at all. We find that a 100 percent increase in import competition increases the intensive margin of offshoring by 6 percent.

\section{[Insert Table 3 about here]}

\footnotetext{
${ }^{17}$ The new EU countries include the Czech Republic, Estonia, Hungary, Latvia, Lithuania, Poland, the Slovak Republic, Slovenia, Cyprus, and Malta, which joined the EU in 2004, and Bulgaria and Romania, which joined in 2007. The corresponding instrumental variable is calculated as the total export values from new EU member countries to high-income countries.

${ }^{18}$ We classify companies as high-productivity ones if they feature a productivity above the 75 th percentile of the industry distribution. Firms that apply for at least one patent over the sample period are classified as tech companies. Firms' patents are drawn from the 2015 PATSTAT patent dataset from the European Patent Office, which contains detailed information on all patent applications from every patent office in the world by the year 2015. We count every patent owned by Danish firms, regardless of the patent office that granted the patent rights. We combine the firm-level data with patent applications through matching by the name and address of the headquarters, as in Bloom et al. (2016).
} 


\subsection{Import Competition and Servitization}

Next, we examine the impact of import competition on manufacturing firms' servitization. Table 4 uses as the dependent variable a dummy equal to 1 if the firm switches completely and permanently out of manufacturing and does not offshore production (i.e., servitization). In column 1, we find a negative but statistically insignificant correlation with servitization in response to Chinese import competition in a probit specification. The linear probability model with firm fixed effects in column 2 reveals that an increase in import competition in the 4-digit manufacturing industries does not significantly affect the probability of servitization, either.

Now, we turn to our instrumental variable approach in column 3. The first-stage coefficient on the instrument is significant and positive, as expected (see the bottom panel of column 3), and the first-stage F-stat on the instrument is above 17, as in the previous table. The second-stage IV results show that Chinese import competition does not have a significant impact on firms' servitization, either. ${ }^{19}$ Similar results are obtained by using our alternative definition of import competition based on new EU member countries (column 5 of Table 4). When we split the sample into high-productivity/tech firms versus the other companies, the result suggests that import competition does not induce servitization for any type of firm in our sample (columns 6 and 7).

In addition, we consider the impact of import competition on firms' joint probability of offshoring and switching out to the service industry (i.e., probability of turning into a company that changes industry code but keeps an indirect involvement in production through offshoring) in column 4 of Table 4 . The coefficient estimated on our import competition variable is positive but not statistically significant, either. Notice that only a negligible share of companies engaged in this joint practice (less than 1 percent). ${ }^{20}$

[Insert Table 4 about here]

\footnotetext{
${ }^{19}$ Similar results available upon request are obtained when we examine the probability of offshoring at time $t$ and servitizing one, two or three years later. The corresponding share of firms that offshore in a given year and servitize later in the sample period are correspondingly very low (below 0.5 percent). This result shows that offshoring is not a stepping stone strategy towards servitization for our sample of Danish firms.

${ }^{20}$ Relatedly, the share of companies that switch out of service and make a transition to the manufacturing industry is also small (around 0.5 percent).
} 
Overall, the results reported in Tables 3 and 4 provide compelling evidence that offshoring and not servitization is the most predominant and significant reaction of Danish companies to foreign import competition, especially if we focus on the group of high-productivity/tech firms. An exogenous increase in import competition from China increases the likelihood of Danish firms to offshore production activities abroad, but it does not increase their servitization probability. ${ }^{21}$

\subsection{The Case of Portugal}

Thus far, the empirical analysis has documented the effects of import competition on the propensity of firms in Denmark to either offshore or servitize. In this section, we extend our investigation to Portugal to assess the generalizability of our findings reported in the previous section. We believe that comparing Denmark to Portugal offers useful insights for the following reasons. First, both countries are small, highly trade-oriented and have similar exposure to Chinese import competition over the sample period considered in the empirical analysis (see Figure 5 below).

Second, these economies are characterized by different institutional frameworks, such as different labor and product market institutions. On the one hand, Denmark has an extremely flexible labor market, which reduces the frictions hindering labor reallocation across firms within industries or across industries. In contrast, Portugal is characterized by one of the most rigid labor markets in the world (Botero et al., 2004). Furthermore, at the beginning of the 2000s, Denmark (Portugal) ranked as one of OECD countries with the most liberal (restrictive) product market regulation(OECD, 2000). Of course, the two economies differ in many other respects, but the purpose of this comparison aims only to provide suggestive evidence of whether our findings for Denmark are driven by the country's idiosyncratic features or reflect instead a general economic pattern among economies in the EU that are exposed to the China shock.

\footnotetext{
${ }^{21}$ Additional findings reported in the online appendix reveal that the effects of import competition on offshoring are stronger in the 2004-2012 sub-period (see Table A-2). Furthermore, our main results are confirmed when we estimate alternate specifications based on multinomial logit models in which offshoring and servitization are treated as two alternative and independent strategies of a given choice set (see Table A3). Finally, our results for offshoring and servitization are confirmed by estimating discrete duration models, in which the dependent variables are the risks of offshoring and servitization, respectively (see Table A-4).
} 
We replicate the same empirical analysis described in the previous section for Denmark using "Quadros de Pessoal" ( $Q P)$, the matched employer-employee dataset for Portugal. The $Q P$ dataset is comparable to the IDA dataset for Denmark in its structure and content (Buhai et al., 2014). It is an annual, mandatory employment survey administered by the Portuguese Ministry of Employment and covers all firms (with at least one wage earner) and their establishments and employees. The analysis of the Portuguese case is based on all active firms that were ever in manufacturing and had more than 1 employee over the 1995-2012 period. $^{22}$ The individual-level data files are used to measure workforce characteristics (such as the share of high-skill workers) and firm characteristics (such as labor productivity). They are comparable to those used for Denmark. Trade information at the firm level is obtained from Statistics Portugal and merged with the QP dataset.

Following the Danish case, we construct the relevant instruments for Chinese import competition by industry based on information from the U.N. COMTRADE database at the product level. ${ }^{23}$ The link between 3-digit industries, the relevant 4-digit products exported, and the destination countries is provided by Statistics Portugal.

Figure 5 shows basic time-series variation in the share of firms that offshore (top panel), the share of firms that servitize (middle panel) and the import competition variable (bottom panel) over the sample period for the manufacturing industry in Portugal. There is a positive trend for all variables. For example, the offshoring rate increases from 29 at the beginning of the sample period to approximately 36 in 2012.

Figure 6 shows the distribution of offshoring by industry, with the wood industry standing out with the largest shares of firms that offshore. Figure 7 instead presents evidence on the prevalence of servitization by the top five industries of origin and destination. We find that the printing and food industries feature the highest servitization rates (approximately 20 percent of all switchers are concentrated in these two industries combined), followed by machinery and equipment, chemicals, and fabricated metal products, each accounting for

\footnotetext{
${ }^{22}$ The year 2001 is missing, as no data were collected at the worker level by the Portuguese Ministry of Employment in this year.

${ }^{23}$ The Portuguese Classification of Economic Activities (CAE, comparable to NACE) underwent several changes over the period considered. To perform the empirical analysis over the same period covered by the Danish data (1995-2012), we standardize all industry classifications according to the earlier versions of NACE rev. 1.1, which is more aggregated than later versions (NACE rev. 2). This corresponds to approximately 80 (3-digit) industries every year.
} 
slightly less than 10 percent of servitization firms. The most popular destination industries are the wholesale and retail trade industries (more than 50 percent of all servitization firms end up in one of these service industries). Approximately 20 percent of all servitization firms move to other service industries that are traditionally low-skill intensive, such as construction and transport.

Similar to the Danish case, Figure 8 shows that the share of high-skill (low-skill) workers is consistently higher (lower) in offshoring firms compared to servitization firms over the sample period. The gap in the shares of high-skill workers between the two types of firms become even wider towards the end of the sample period.

\section{[Insert Figures 5, 6, 7 and 8 about here]}

The main results for Portugal are presented in Table 5. In columns 1-5, we examine the extensive margin of offshoring. Similar to Denmark, a 100 percent increase in import competition is associated with an approximately one percent increase in the probability that the firm will offshore after controlling for firm characteristics and firm, sector and year fixed effects (column 2). A probit specification provides a marginal coefficient of the same sign (column 1). When we estimate the impact using our instrumental variable approach (column $3)$, the coefficient is positive and statistically significant (1.5 percent increase in the corresponding probability for 100 percent increase in import competition). Import competition triggers an increase in Portuguese firms' offshoring, especially when we focus on tech- or high-productivity firms (see columns 4 and 5).

When we examine servitization, the coefficient estimated on import competition is negative across all specifications but statistically insignificant, consistently with the evidence reported for Denmark. According to our IV results, a 100 percent increase in Chinese import competition at time $t-1$ decreases the probability of servitization by approximately 10 percent (column 8), but the coefficient is not precisely estimated. These results hold for both the sub-samples focusing on or excluding tech or high-productivity firms (columns 10 and 11). In addition, in column 9, the impact of import competition on the joint practice of offshoring and switching to service is positive but again not precisely estimated.

[Insert Table 5 about here] 
The similarity in firms' responses to import competition documented in this cross-country comparison suggests the following result. Manufacturing firms operating in small open economies (such as Denmark and Portugal) react to foreign competition from low-wage countries mainly by offshoring production activities and employing more high-skill workers, and not by switching completely and permanently out of manufacturing to conduct low-skill intensive activities within the service industries.

\section{Conclusions}

This paper examines the impact of import competition on firm-level offshoring and servitization decisions. We utilize a detailed employer-employee matched dataset covering a large sample of Danish and Portuguese firms in the manufacturing industry from 1995 to 2012. Our results provide new insights into firms' strategies to cope with foreign competition.

First, we find that an exogenous increase in import competition leads to a significant increase in firm-level offshoring at both the extensive and intensive margins. This result indicates that import competition from low-wage countries, like China, increases the need for firms to relocate production activities abroad and to employ more high-skill workers domestically, perhaps to focus on knowledge-intensive tasks, such as R\&D activities. This relationship is stronger for high-performing companies, such as high-productivity or tech firms, than for low-performing ones. Second, firms do not seem to respond to increased import competition by switching completely and permanently out of manufacturing (i.e., servitization). Third, the above results are consistent across Denmark and Portugal.

Policy makers should be aware of the strategies most commonly undertaken by firms in the face of foreign import competition. In both the Danish and Portuguese cases, the main effect of Chinese import competition is to induce manufacturing firms to offshore production and employing more high-skill workers. Public policies should aim at strengthening the retraining of low-skill workers who are displaced by offshoring firms. 


\section{References}

Angrist, J. D. and Pischke, J.-S. (2010). The Credibility Revolution in Empirical Economics: How Better Research Design Is Taking the Con out of Econometrics. Journal of Economic Perspectives, 24(2):3-30.

Autor, D. H., Dorn, D., and Hanson, G. H. (2013). The China Syndrome: Local Labor Market Effects of Import Competition in the United States. American Economic Review, 103(6):2121-2168.

Autor, D. H., Dorn, D., and Hanson, G. H. (2015). Untangling trade and technology: Evidence from local labour markets. The Economic Journal, 125(584):621-646.

Bernard, A., Fort, T., Smeets, V., and Warzynski, F. (2019). Heterogeneous globalization: Offshoring and reorganization. Mimeo, Tuck School at Dartmouth.

Bernard, A. B., Fort, T. C., Smeets, V., and Warzynski, F. (2020). Heterogeneous globalization: Offshoring and reorganization. Working Paper 26854, National Bureau of Economic Research.

Bernard, A. B., Smeets, V., and Warzynski, F. (2017). Rethinking Deindustrialization. Economic Policy, 32(89):5.

Bloom, N., Draca, M., and Reenen, J. V. (2016). Trade Induced Technical Change? The Impact of Chinese Imports on Innovation, IT and Productivity. Review of Economic Studies, 83(1):87-117.

Botero, J. C., Djankov, S., La Porta, R., Lopez-de Silanes, F., and Shleifer, A. (2004). The Regulation of Labor. Quarterly Journal of Economics, 119(4):1339-1382.

Breinlich, H., Soderbery, A., and Wright, G. C. (2018). From Selling Goods to Selling Services: Firm Responses to Trade Liberalization. American Economic Journal: Economic Policy, 10(4):79-108. 
Buhai, I. S., Portela, M. A., Teulings, C. N., and van Vuuren, A. (2014). Returns to tenure or seniority? Econometrica, 82(2):705-730.

Damm, A. P. and Dustmann, C. (2014). Does Growing Up in a High Crime Neighborhood Affect Youth Criminal Behavior? American Economic Review, 104(6):1806-1832.

Dauth, W., Findeisen, S., and Suedekum, J. (2014). The Rise Of The East And The Far East: German Labor Markets And Trade Integration. Journal of the European Economic Association, 12(6):1643-1675.

Feenstra, R. C. and Hanson, G. H. (1999). The impact of outsourcing and high-technology capital on wages: Estimates for the united states, 1979-1990. The Quarterly Journal of Economics, 114(3):907-940.

Ferriere, A., Navarro, G., and Reyes-Heroles, R. (2018). Escaping the Losses from Trade: The Impact of Heterogeneity on Skill Acquisition. 2018 Meeting Papers 1248, Society for Economic Dynamics.

Gu, G. W., Malik, S., Pozzoli, D., and Rocha, V. (2020). Trade-Induced Skill Polarization. Economic Inquiry, 58(1):241-259.

Horrace, W. C. and Oaxaca, R. L. (2006). Results on the Bias and Inconsistency of Ordinary Least Squares for the Linear Probability Model. Economics Letters, 90(3):321 - 327.

Humlum, A. (2019). Robot adoption and labor market dynamics. Mimeo University of Princeton.

Hummels, D., Jørgensen, R., Munch, J., and Xiang, C. (2014a). The wage effects of offshoring: Evidence from danish matched worker-firm data. American Economic Review, 104(6):1597-1629.

Hummels, D., Jørgensen, R., Munch, J., and Xiang, C. (2014b). The wage effects of offshoring: Evidence from danish matched worker-firm data. American Economic Review, 104(6):1597-1629. 
Lodefalk, M. (2017). Servicification of firms and trade policy implications. World Trade Review, 16(1):59-83.

Miguel, E., Satyanath, S., and Sergenti, E. (2004). Economic Shocks and Civil Conflict: An Instrumental Variables Approach. Journal of Political Economy, 112(4):725-753.

OECD (2000). Product market competition and economic performance. OECD Publishing, Paris.

OECD (2013a). Oecd economic surveys: Denmark, 2013. Technical report.

OECD (2013b). Oecd economic surveys: Portugal, 2014. Technical report.

OECD (2015). Oecd skills strategy diagnostic report: Portugal. OECD surveys.

Olea, J. L. M. and Pflueger, C. (2013). A robust test for weak instruments. Journal of Business 83 Economic Statistics, 31(3):358-369. 
Figure 1: Import Competition, Servitization, Offshoring: Time Series Variation (Denmark)
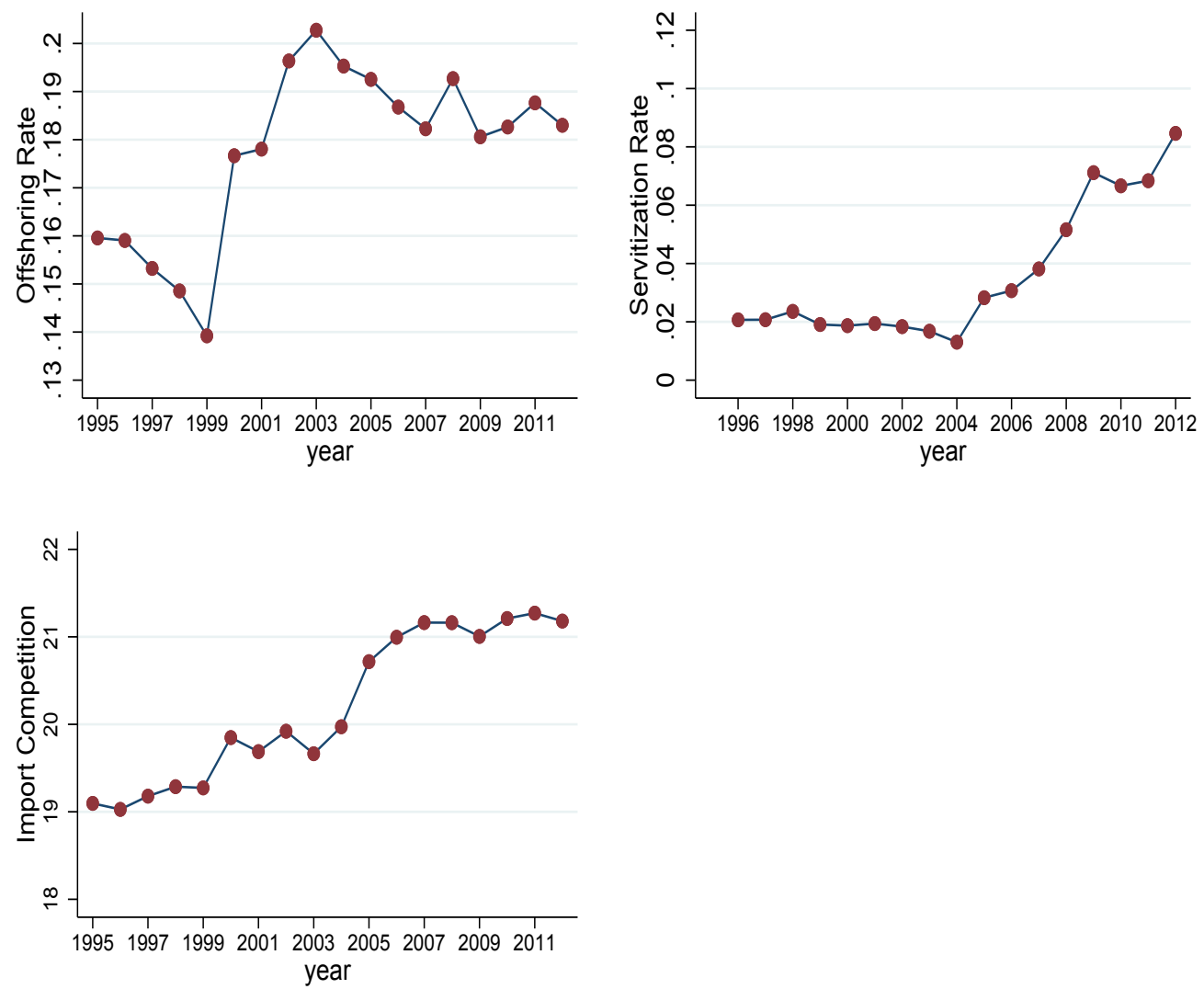

Notes: The share of offshoring firms is the year-specific share of firms that engage in offshoring activities. The share of firms servitizating is the year-specific share of firms that completely and permanently switch out of manufacturing. Import competition is the year-specific average log of the weighted sum of Chinese import values of all HS products. 
Figure 2: Offshoring by Industry (Denmark)

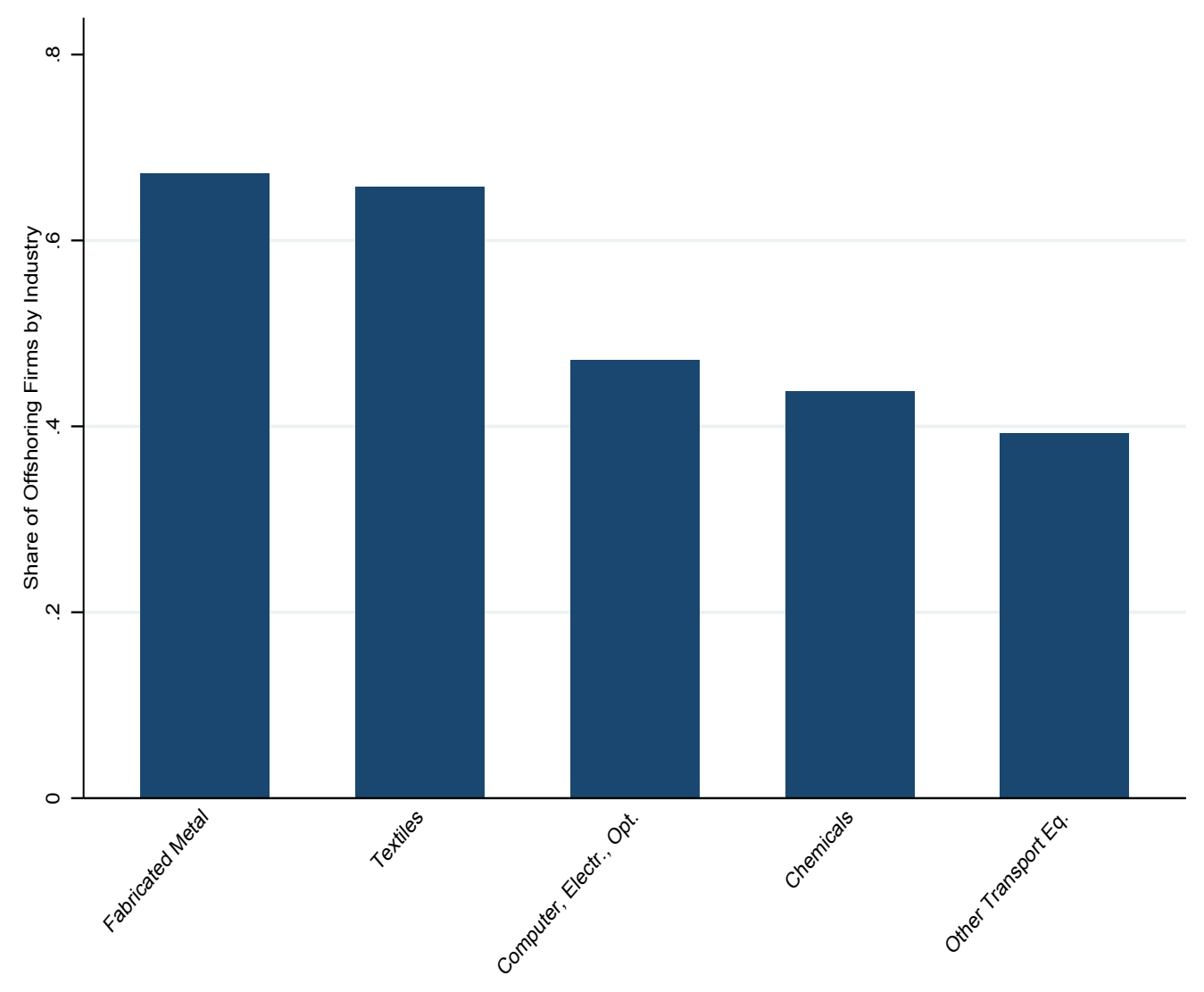

Notes: Share of offshoring firms within each 2-digit Danish industry code (1995-2011). 
Figure 3: Servitization by Industry of Destination and of Origin (Denmark)
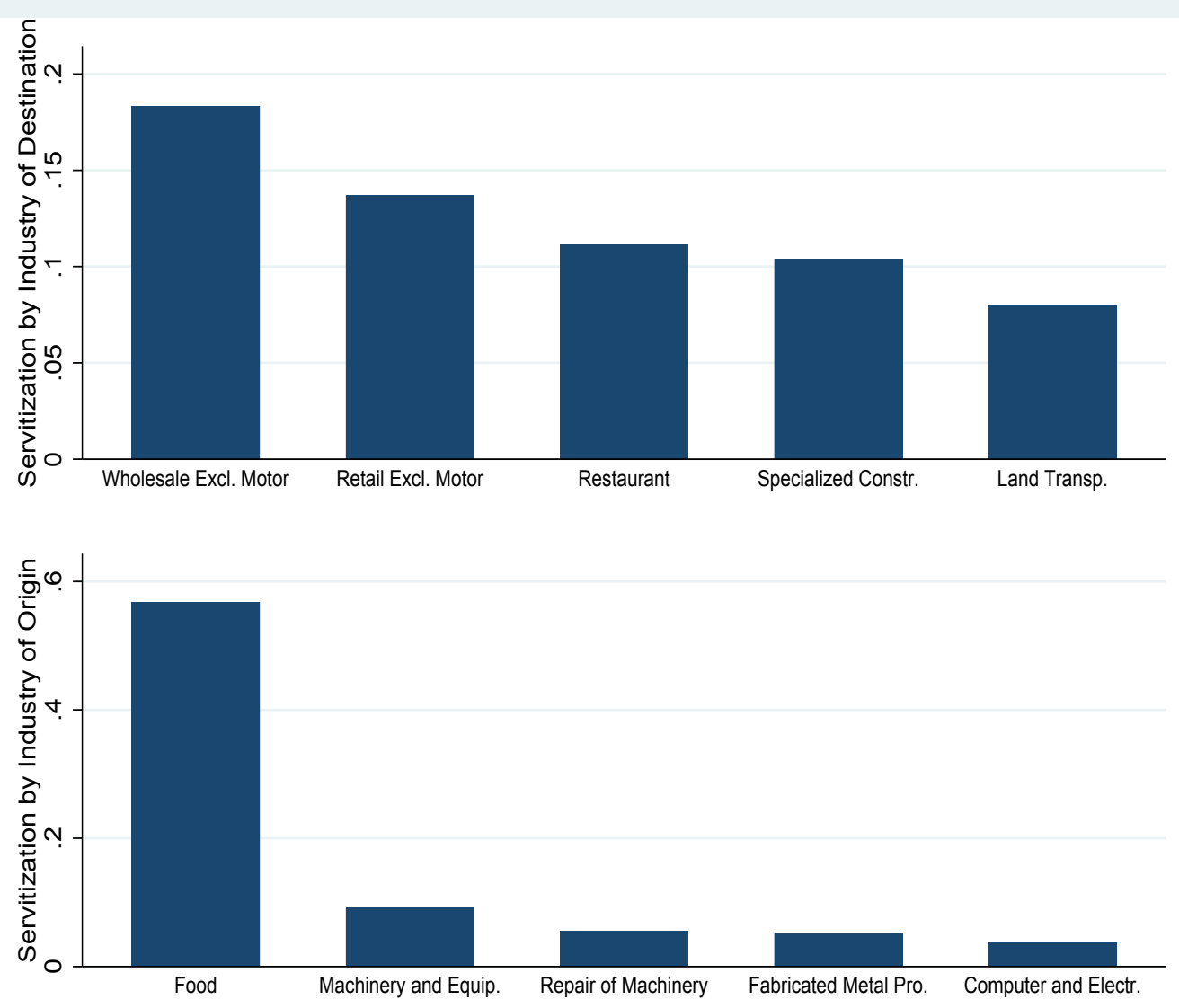

Notes: The share of firms that switch completely and permanently out of manufacturing (servitization rate) by the industry of destination (top panel) and by the industry of origin (bottom panel), (average, 1995-2012). 
Figure 4: Share of Differently Skilled Workers: Time Series Variation by Firm Type (Denmark)
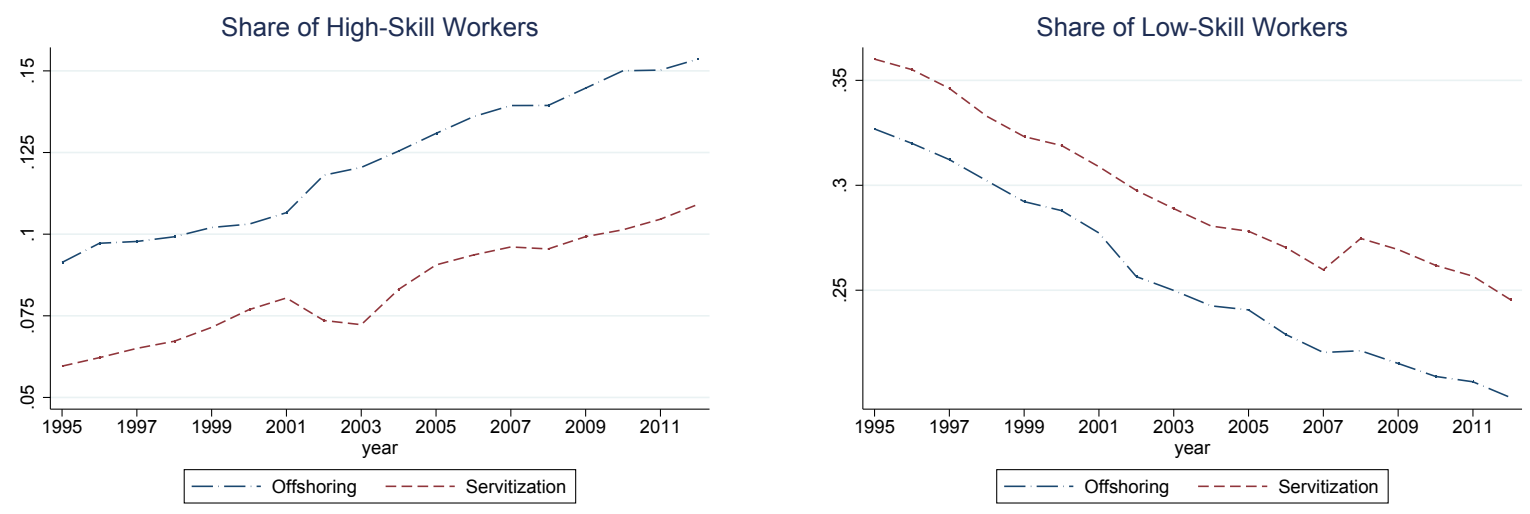

Notes: High-skill workers are workers with at least a college degree. Low-skill workers are workers with less than a secondary education. The "offshoring" sample includes firms that offshore at least once over the whole sample period. The "servitization" sample includes firms that cease any involvement in production and switch completely and permanently out of manufacturing. 
Figure 5: Import Competition, Servitization, Offshoring: Time Series Variation (Portugal)
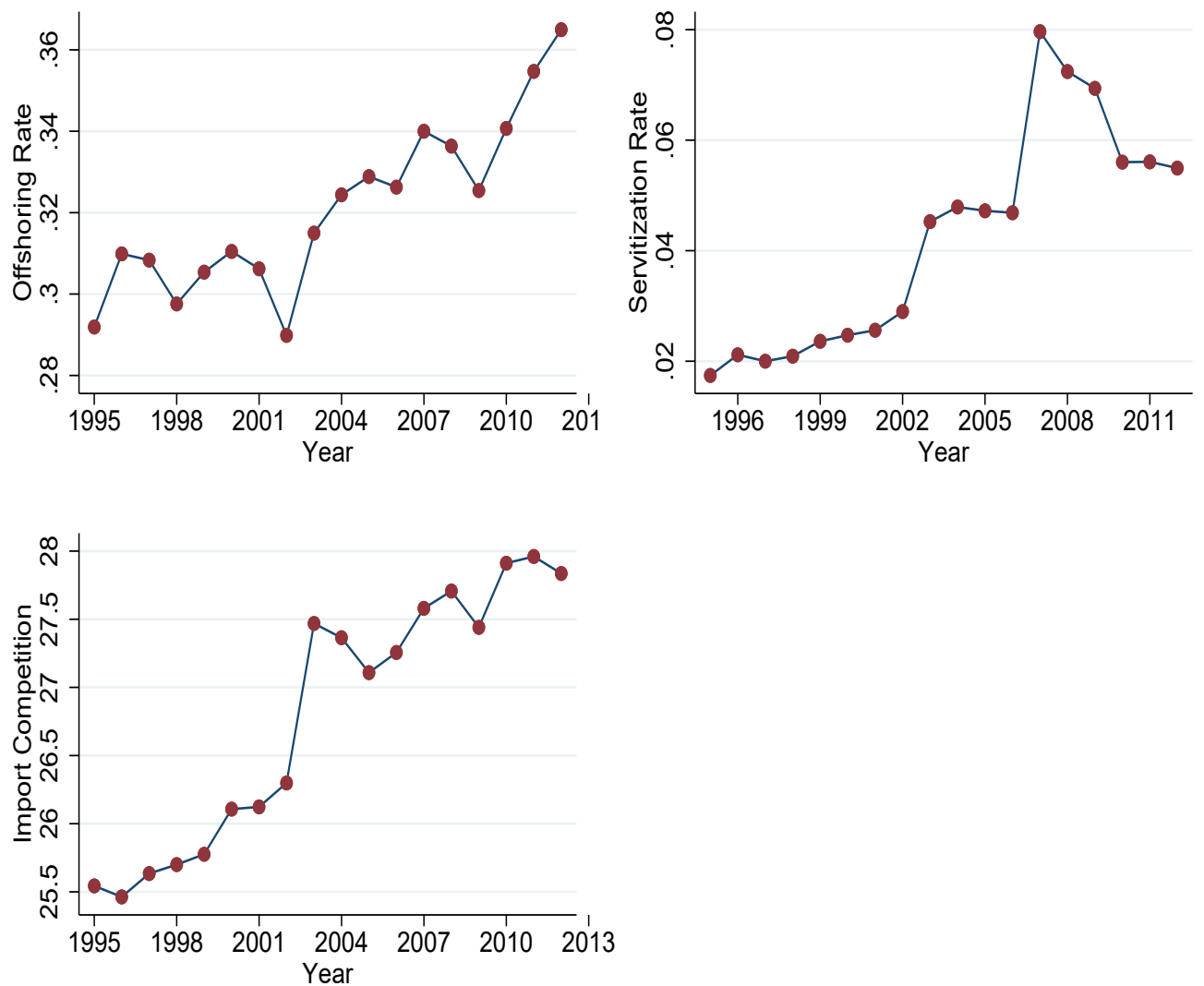

Notes: The share of offshoring firms is the year-specific share of firms that engage in offshoring activities. The share of firms switching out of manufacturing (servitization rate) is the year-specific share of firms that switch out of manufacturing. Import competition is the year-specific average log of the weighted sum of Chinese import values of all HS products. 
Figure 6: Offshoring by Industry (Portugal)

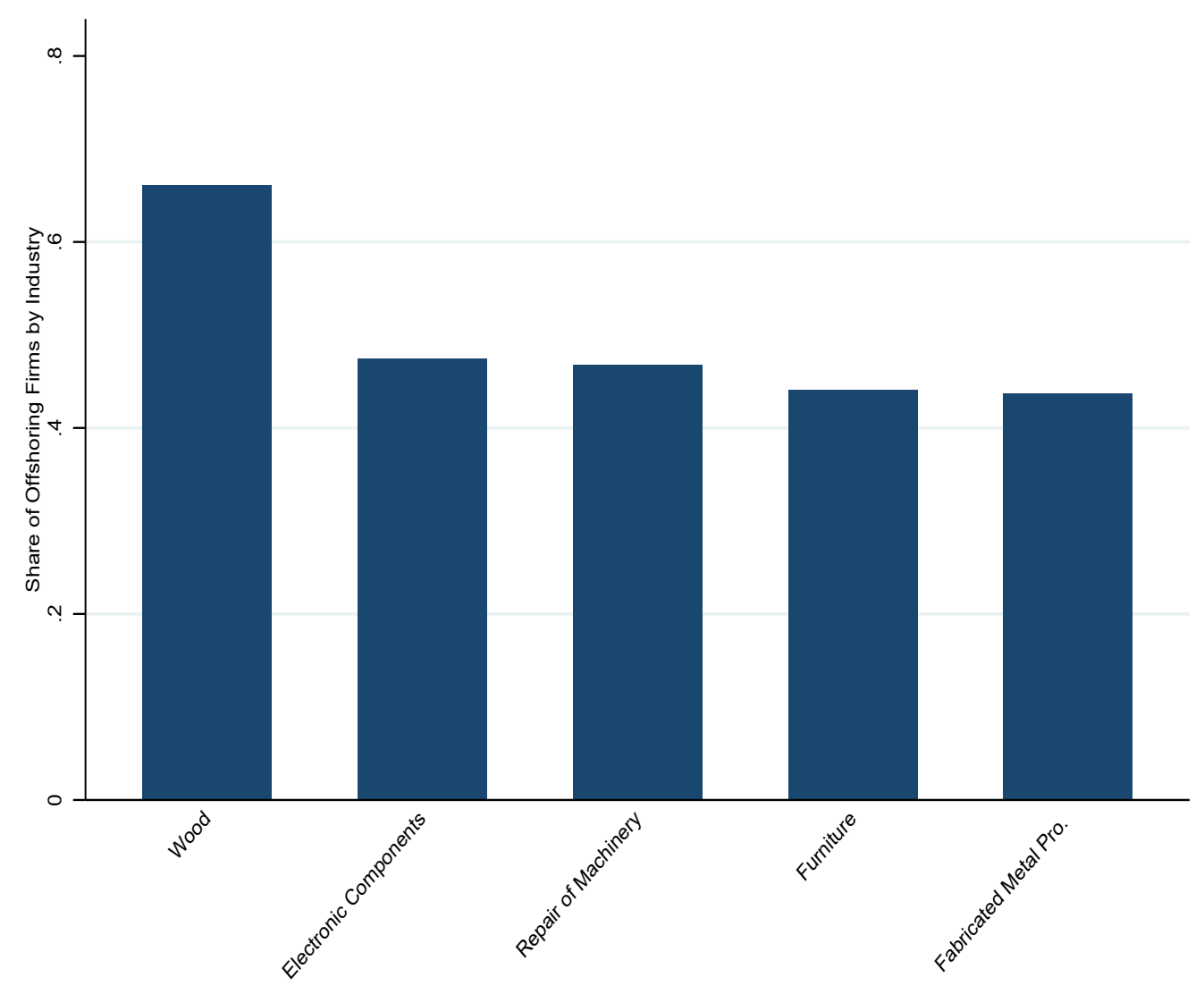

Notes: Share of offshoring firms within each 2-digit Danish industry code (1995-2011). 
Figure 7: Servitization by Industry of Destination and of Origin (Portugal)
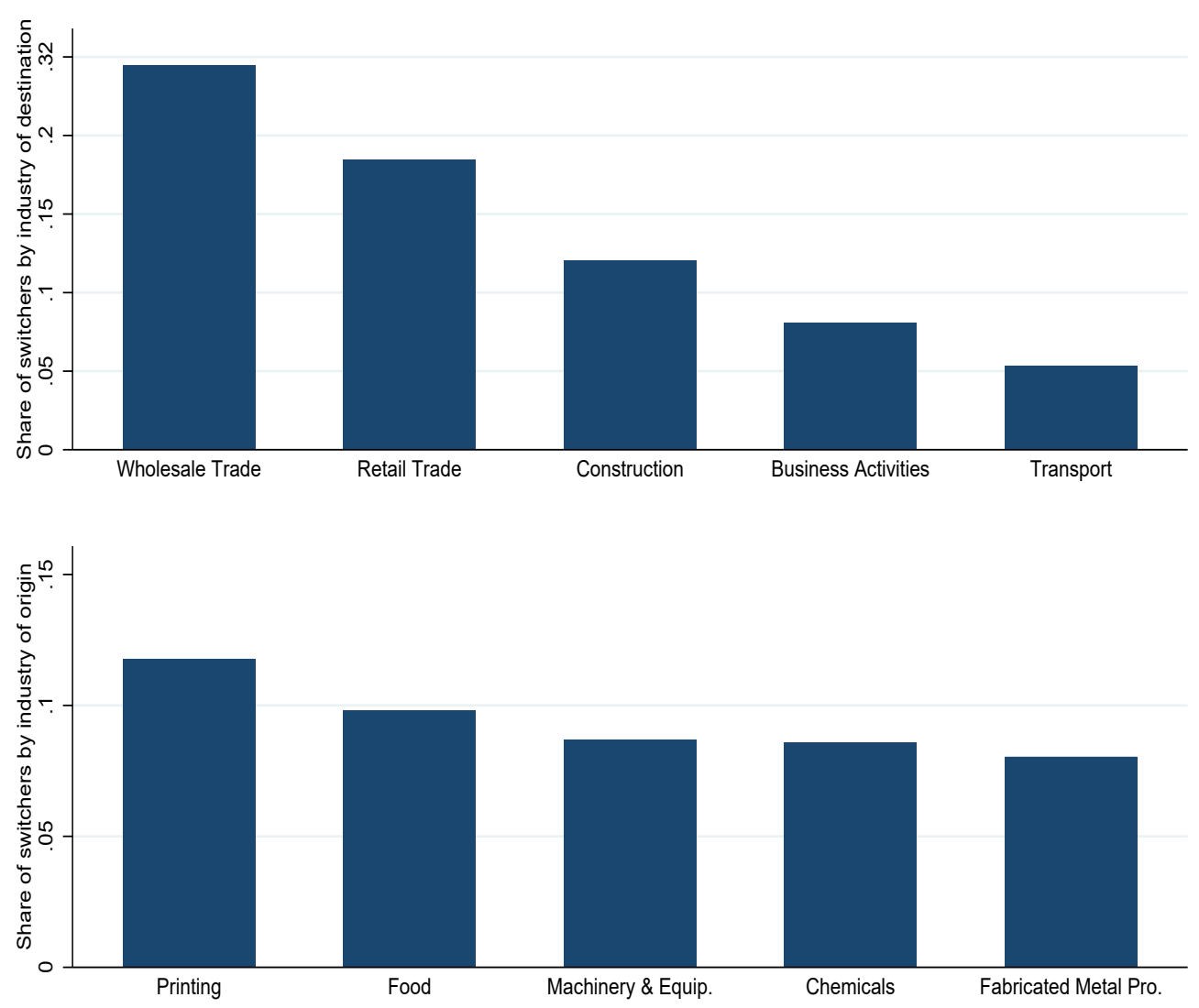

Notes: Share of firms that switch completely and permanently out of manufacturing (servitization rate) by industry of destination (top panel) and by industry of origin (bottom panel).

Figure 8: Share of Differently Skilled Workers: Time Series Variation by Firm Type (Portugal)
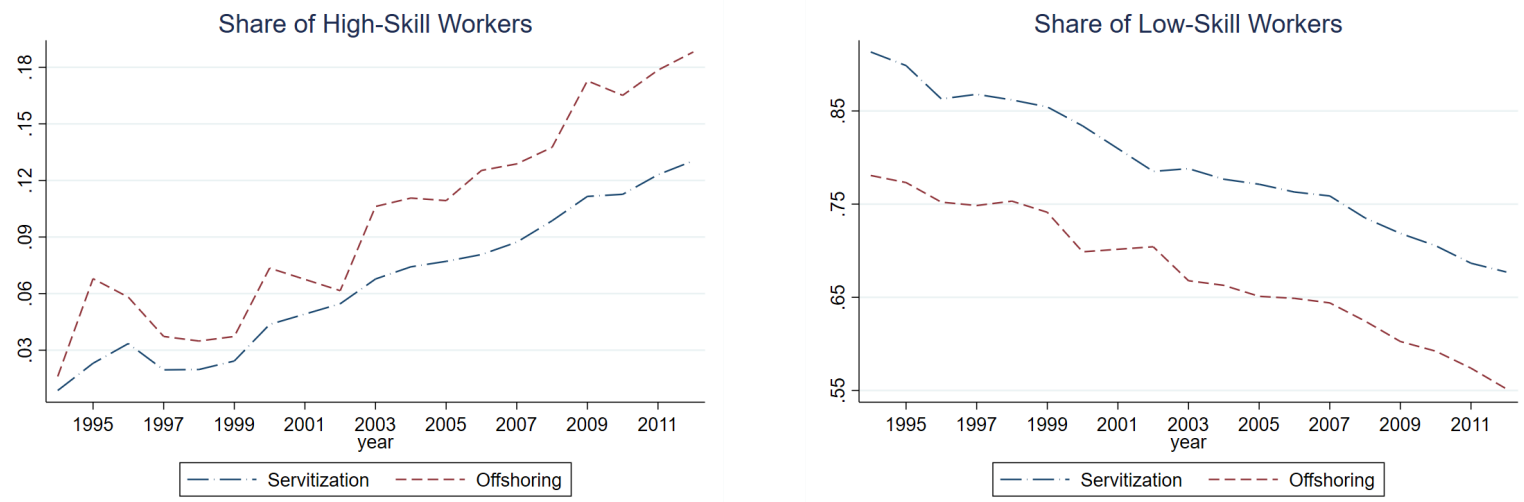

Notes: High-skill workers are workers with at least a college degree. Low-skill workers are workers with less than secondary education. The "offshoring" sample includes firms that offshore at least once over the whole sample period. The "servitization" sample includes firms that cease any involvement in production and switch completely and permanently out of manufacturing. 


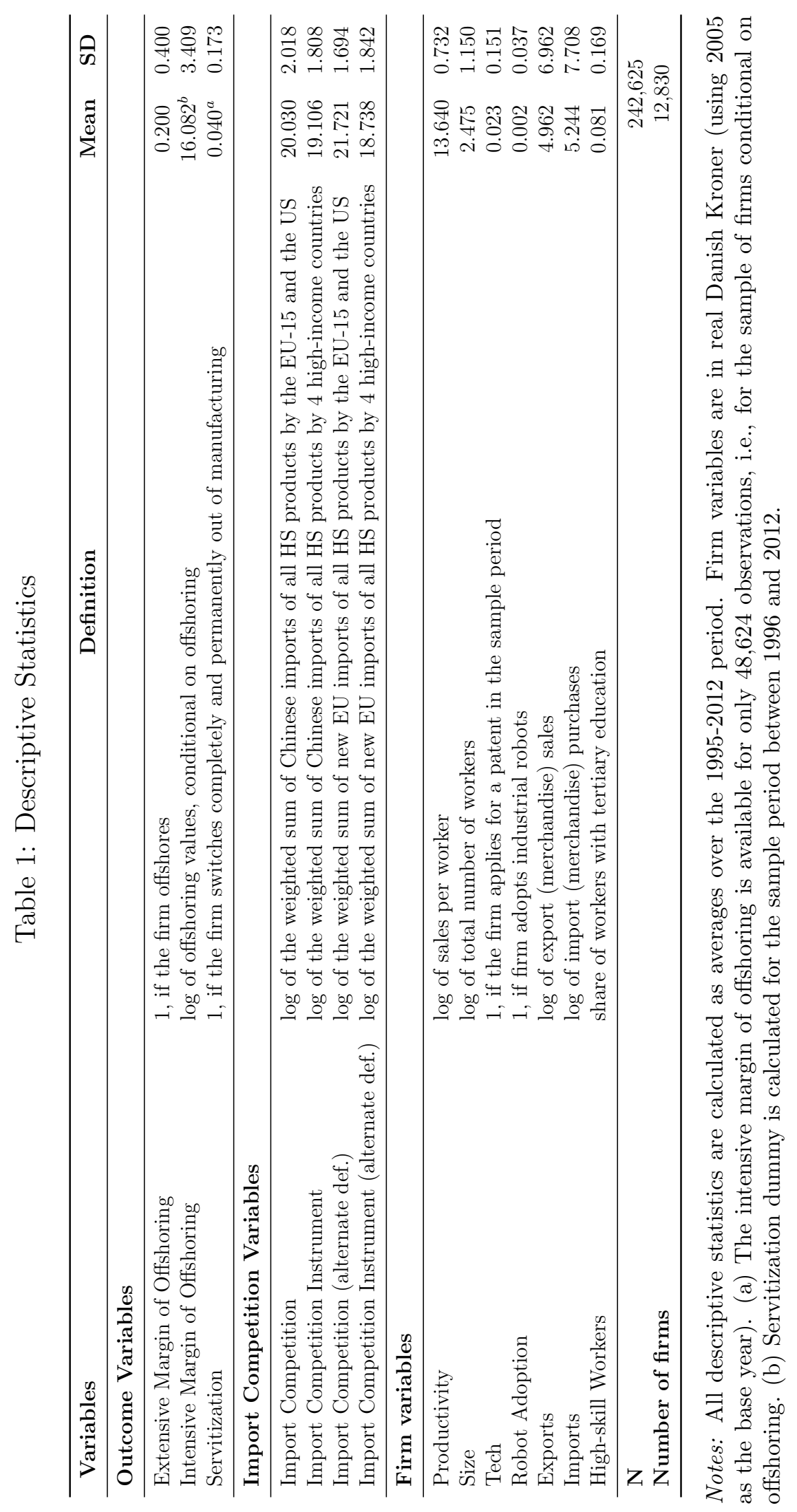




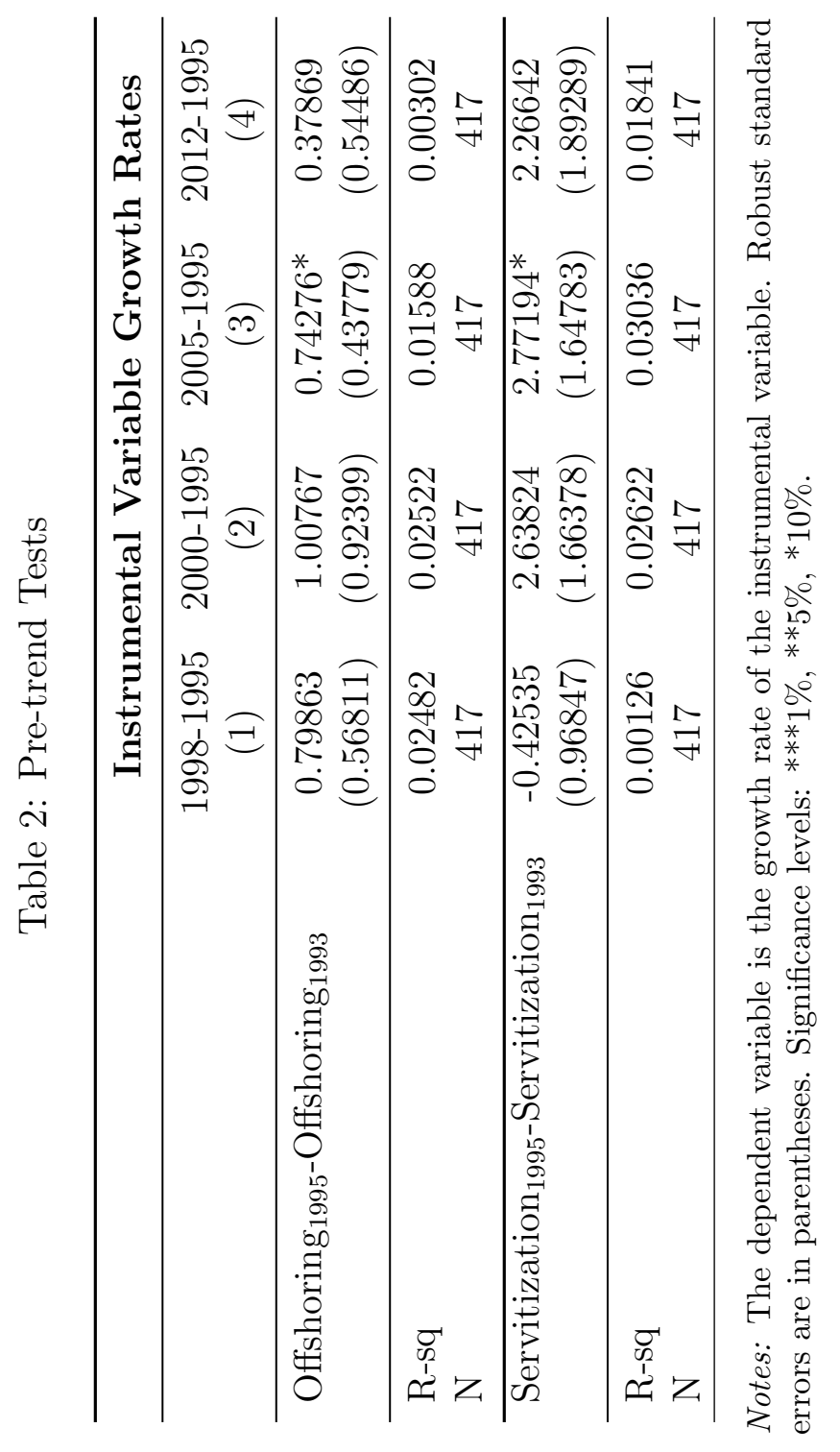




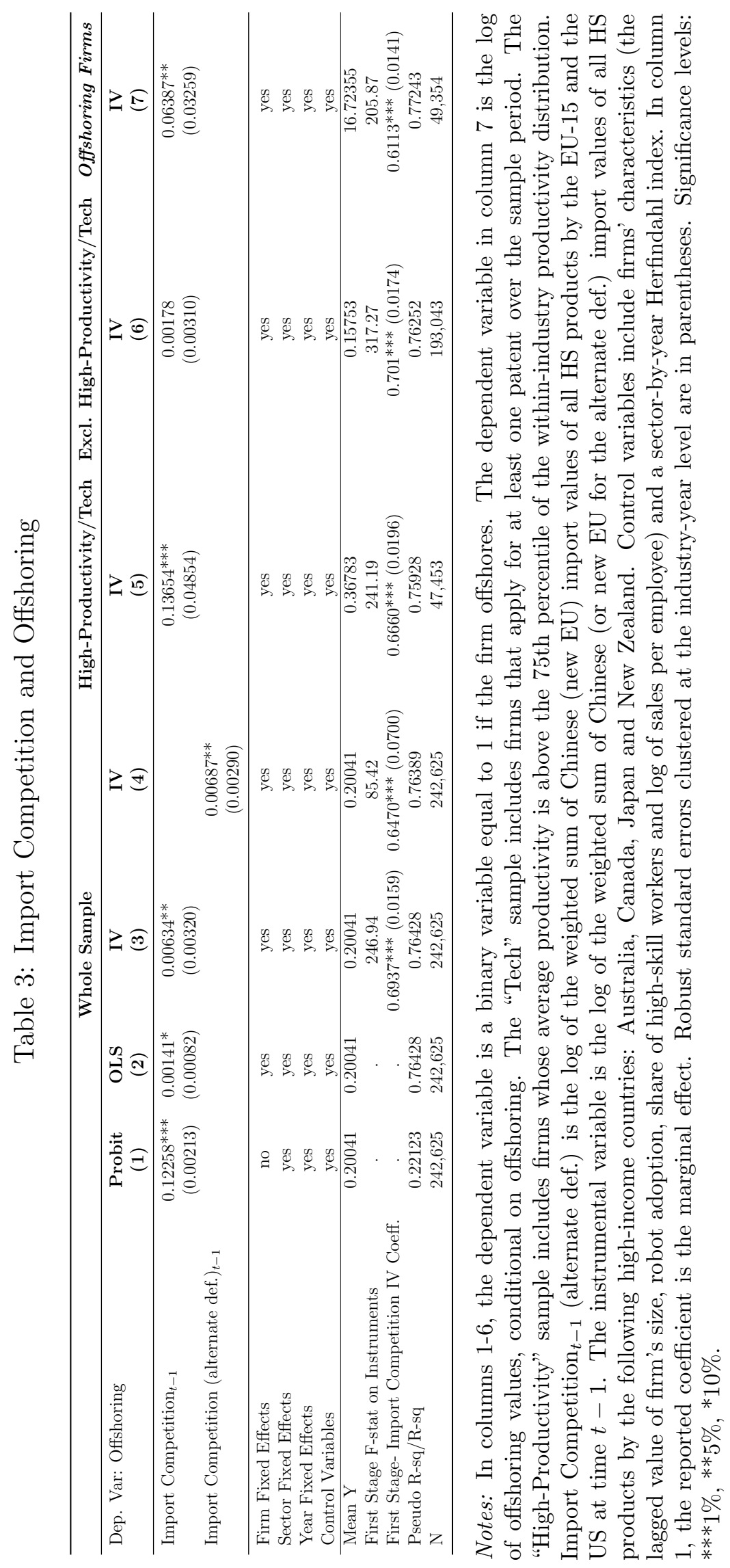




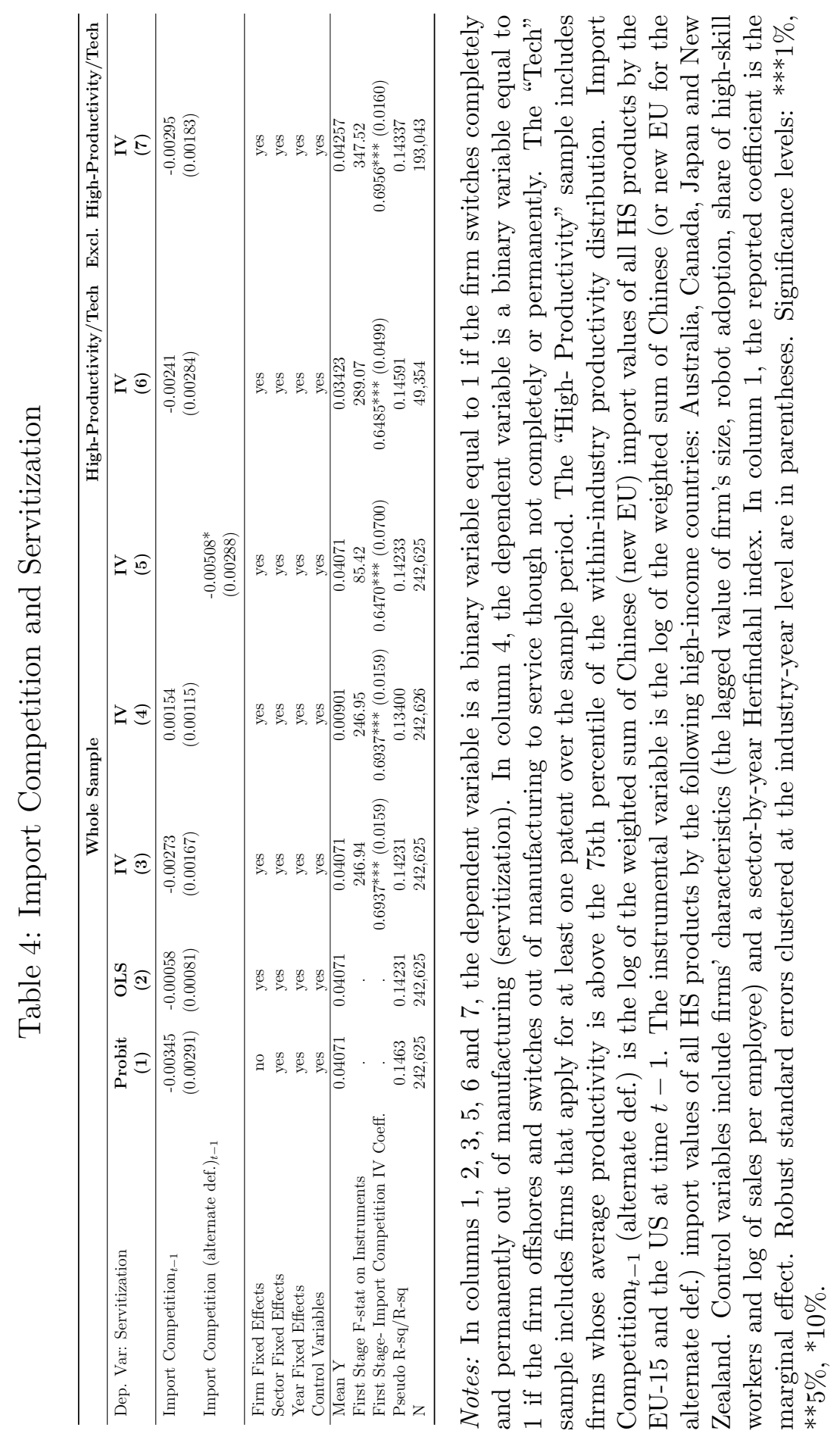




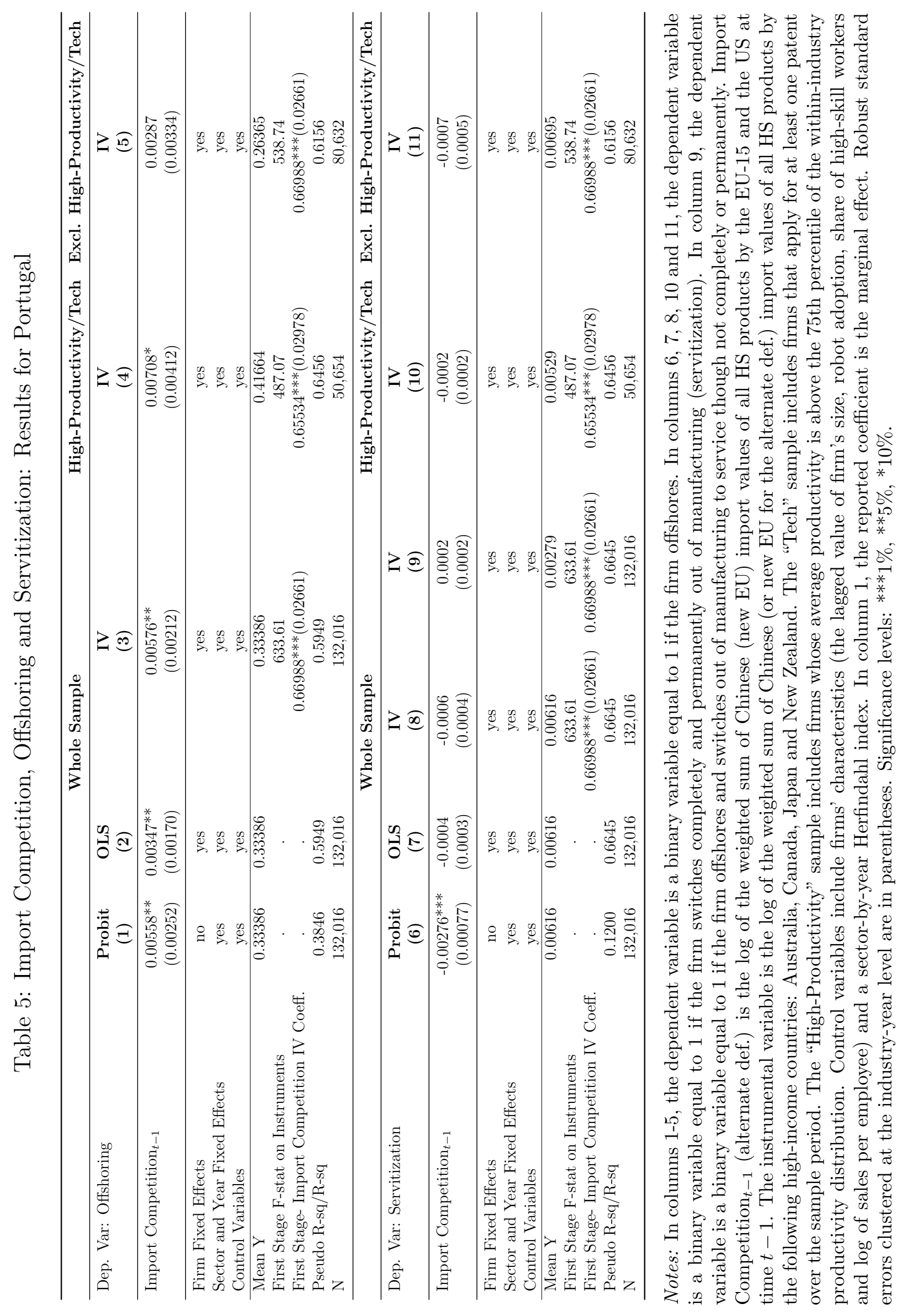


Online Appendix Chinese Import Competition, Offshoring and Servitization: Additional Results

December 30, 2020 


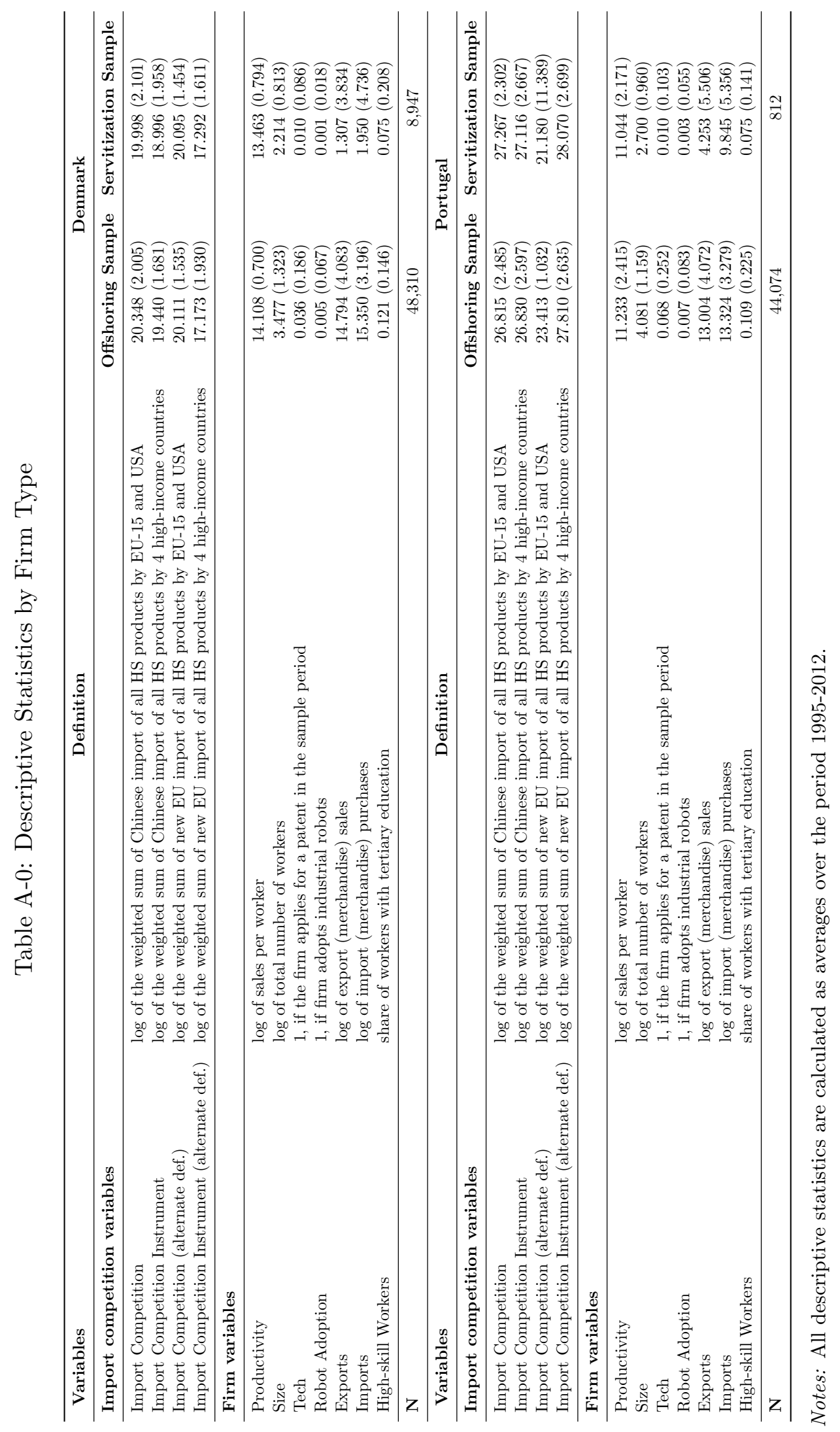




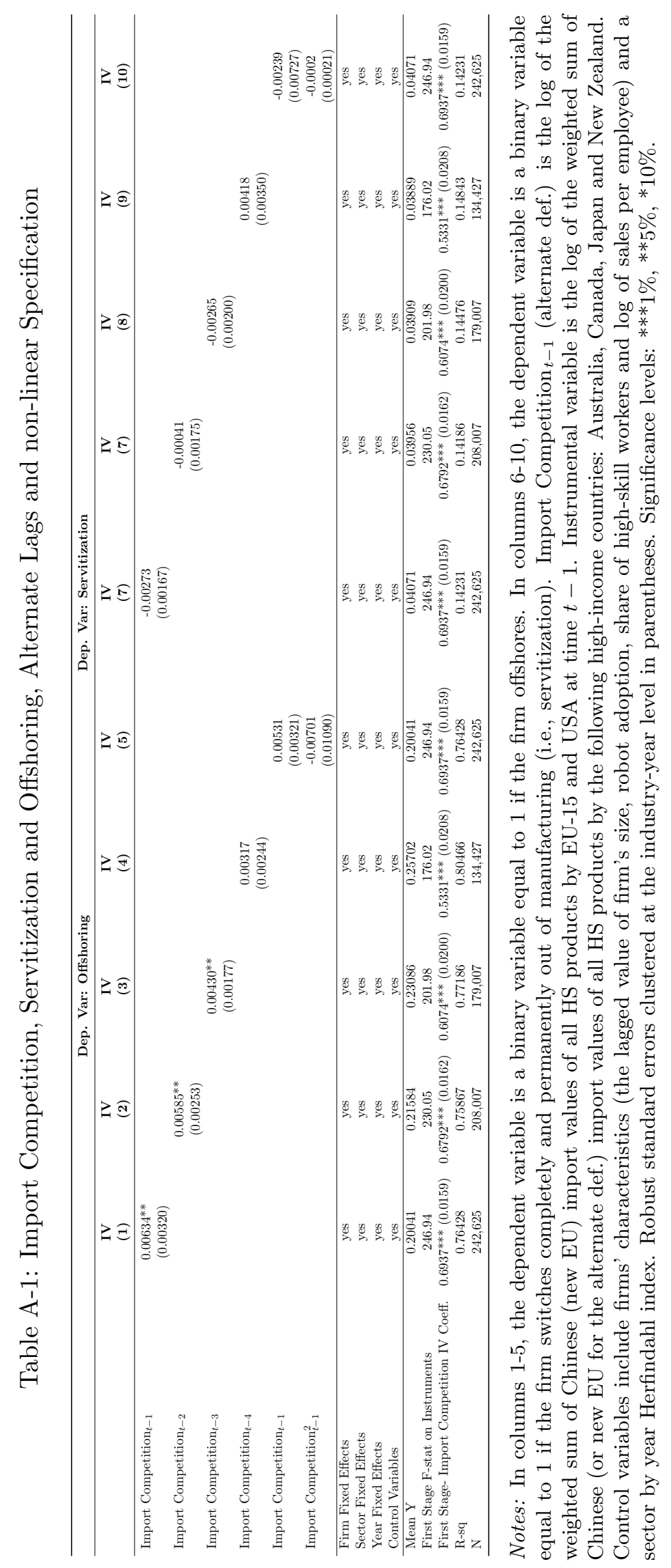




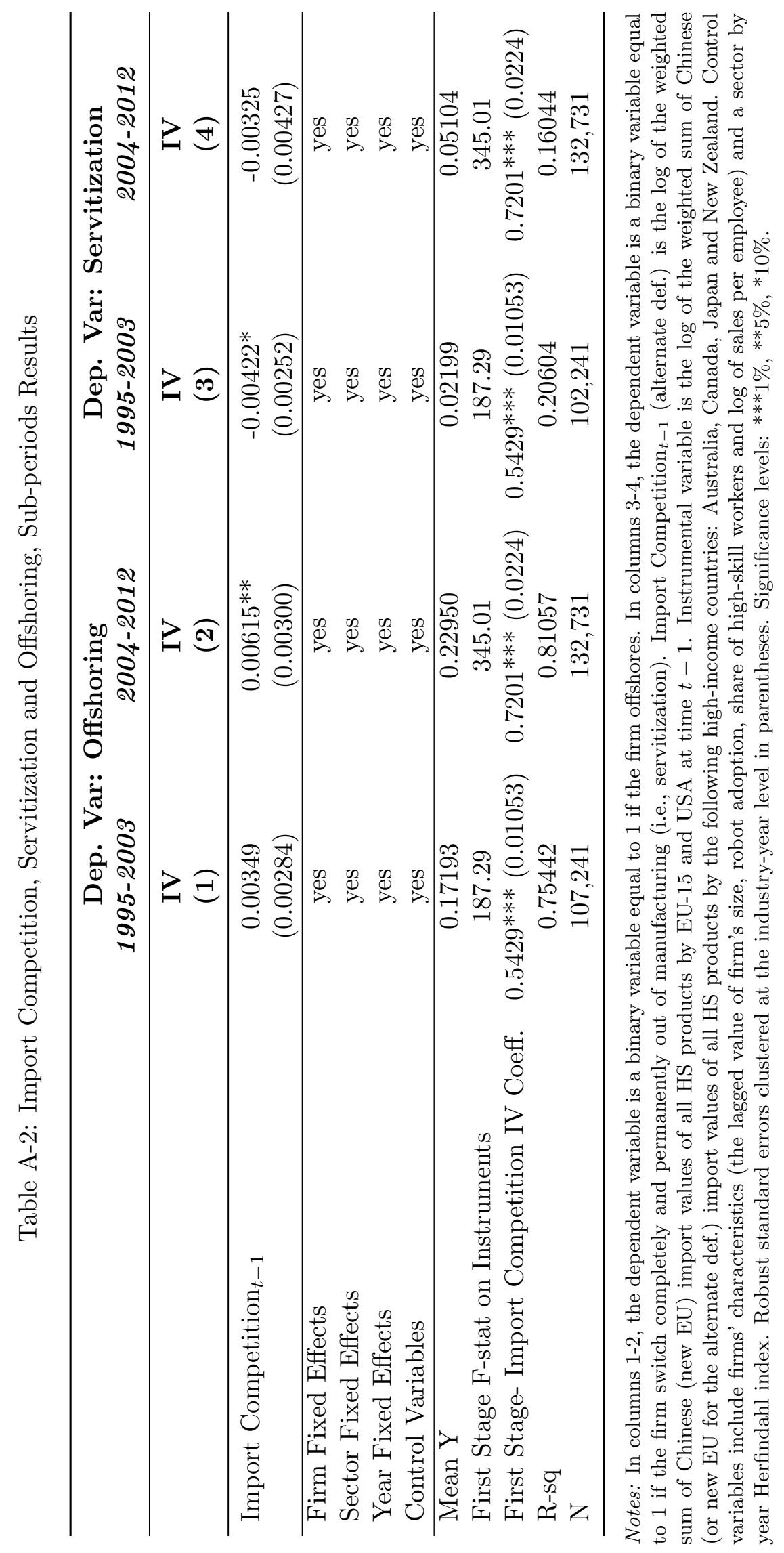




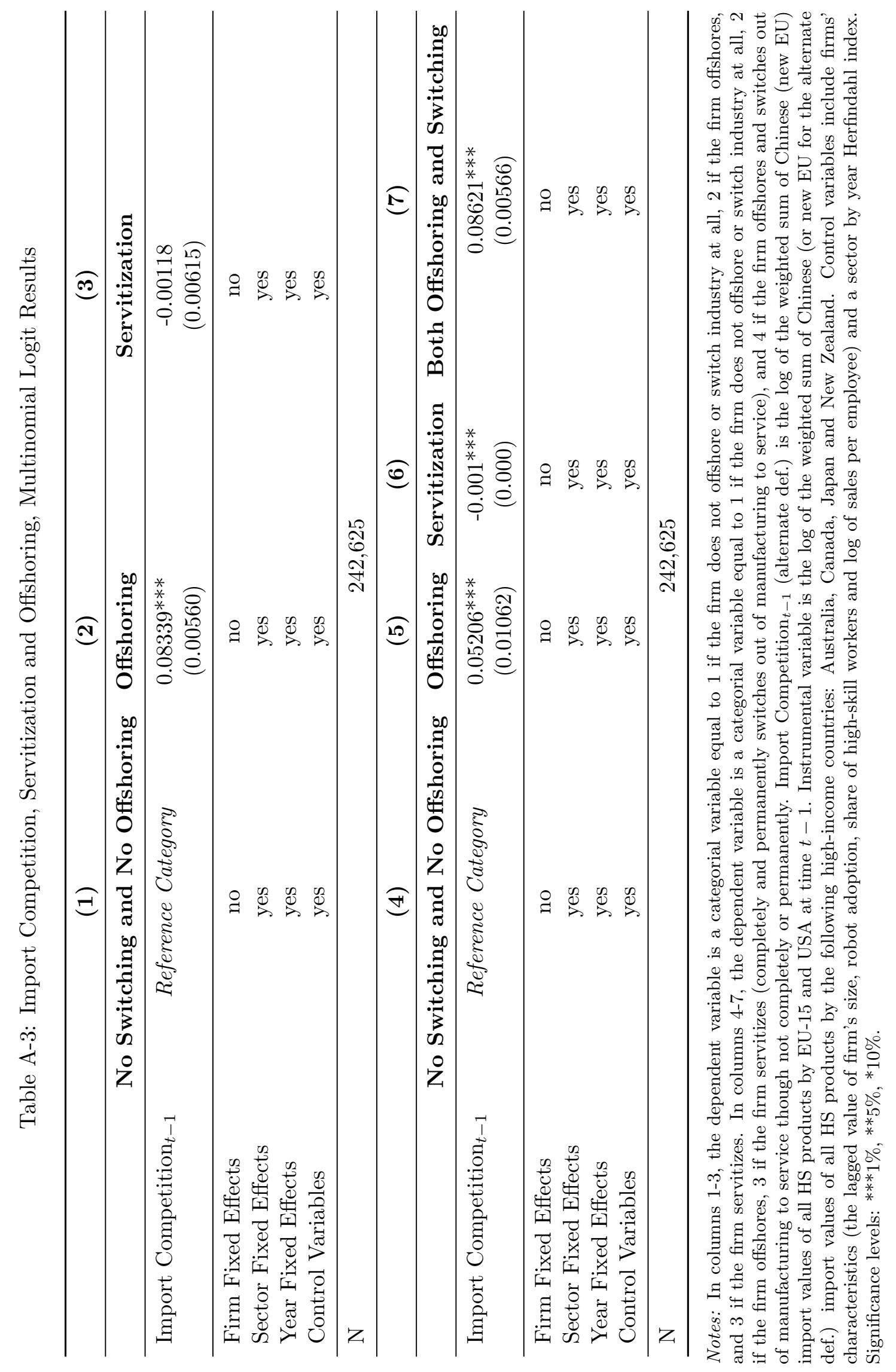




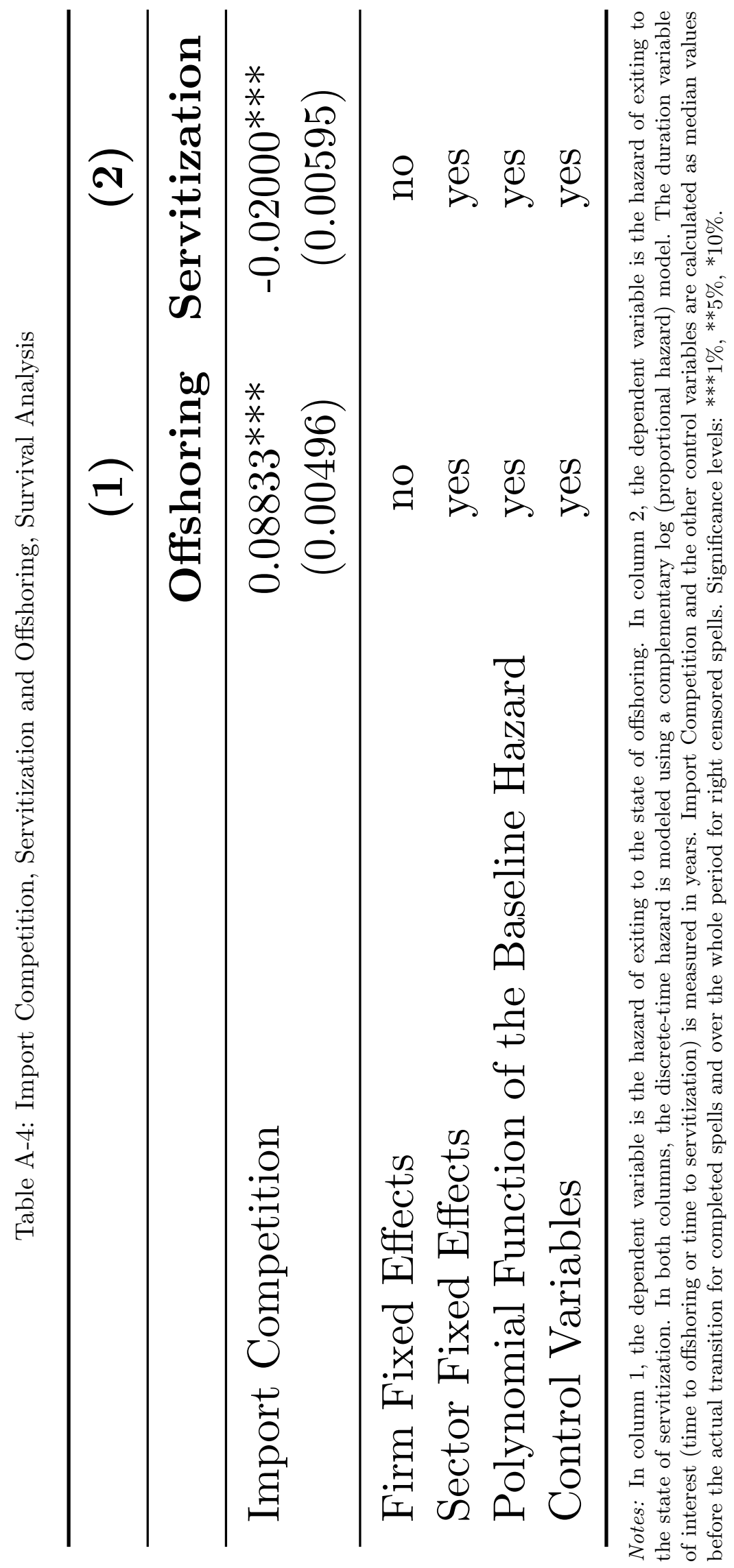

